\title{
Urbanisation and the Political Geographies of Violent Struggle for Power and Control: Mining Boomtowns in Eastern Congo
}

\author{
Karen Büscher
}

\begin{abstract}
This chapter addresses rural-urban transformations in the Kivu provinces, Democratic Republic of Congo (DRC), and more particularly focuses on the complex relationship between dynamics of violent conflict and the emergence of urban mining 'boomtowns'. Mining towns offer fascinating sites from which to investigate the socioeconomic and spatial effects of a protracted history of violence, displacement and militarisation. They are the spatial outcomes of dynamics of the transformative power of violent conflict. Moreover, this chapter demonstrates how they also offer interesting spatial as well as analytical starting points from which to study the political geographies of war dynamics in Eastern DRC. It will be argued that the reason why these mining towns evolve into strategic 'resources' in violent struggles for power and control is to be found in their urban character as much as in the presence of natural resources. As such, this chapter analyses the process of mining urbanisation in the Kivu provinces as part of (armed) elites' spatial politics of power and control. As demographic concentrations and economic nodes, mining towns represent important political, economic and social resources for 'big men', armed groups and the Congolese state in their broader political struggles for power, legitimacy and authority. In a context of fragmented and multi-scalar governance, the urbanisation process of these towns is the outcome of a complex interaction and contestation of different forms of agency. Based on three ethnographic cases of mining towns that emerged from diverse dynamics of artisanal mining activities and forced displacement, this chapter contributes to broader academic and policy debates on the political nature of mining urbanisation in a context of conflict and fragmented governance.
\end{abstract}

\section{Introduction: Mining Towns as Critical Locations of (Violent) Political Struggle in the DRC}

On June 19, 2014, a local radio station Amani ('peace' in Swahili) was inaugurated in Rubaya, a mining town situated in the hills of Masisi, North Kivu, in

(C) KAREN BÜSCHER, 2018 | DOI:10.1163/9789004387942_014

This is an open access chapter distributed under the terms of the prevailing CC-BY-Noricensecatethe time 9004387942 of publication. 
Eastern Congo. The inauguration ceremony, which took place in heavy rain, was widely attended, not least by a big delegation of Congolese government representatives. As part of a larger project on community peace consolidation set up by the American NGO Search for Common Ground, Radio Amani was financed by the Japanese government and launched in cooperation with the United Nations Development Programme (UNDP) and the UN peacekeeping force United Nations Organization Stabilization Mission in Democratic Republic of the Congo (MONUSCO). In front of the cameras and microphones documenting this mediatised event, donors, provincial ministers, as well as local inhabitants expressed their hopes that this 'intercommunity radio', an 'apolitical radio of proximity', would bring together people from different communities to overcome distrust and violence and to build together on the consolidation of peace in the region. ${ }^{1}$

The event is informative of the general image of the mining town of Rubaya, a site of interethnic land conflicts, rebel rule and a militarised economy of natural resources. It presents one of those local sites at which the broader dynamics of violent conflict characterising Eastern Congo's Kivu provinces come together and are being translated into local precarities, conflicts and violent livelihoods. The choice of Rubaya as one of the stations for the intercommunity peace-building radio project is further informed by the fact that this mining town presents an ideal site for a broad reach: in contrast to its rural surroundings, Rubaya is marked by a dense demographic concentration and a relatively well-developed radio and mobile data network. With its estimated 70,000 inhabitants, this mining town is a crowded centre, where miners, traders, state officials, IDPs (internally displaced persons) and taxi drivers from very different places and ethnic backgrounds meet in search of livelihoods, protection or leisure. Further, the event also points at the position of this mining town on the map of international humanitarian, development and peacebuilding interventions. The presence of IDP camps in the vicinity of the town, but especially the militarisation of artisanal mining activities, has attracted the attention of several international actors. In recent years, several NGOs, advocacy organisations and activists have engaged in the struggle against socalled conflict minerals. Since it is the first North Kivu 'sector' in the so-called traceability process, ${ }^{2}$ Rubaya has been put on the international map by a wide variety of researchers, activists, journalists and NGO staff. Rubaya's appearance

1 See Radio Okapi (2014) 'Nord-Kivu: Création d'une radio communautaire à Rubaya' https:// www.radiookapi.net/regions/nord-kivu/2014/06/20/nord-kivu-creation-dune-radio -communautaire-rubaya (accessed on 1 November 2017).

2 Organised by International Tin Association (ITA) Ltd. See Verbrugge et al. (2011) and Geenen (2016) for more information on this supply chain traceability initiative. 
in US campaigns, for example, has largely reproduced the dominant narrative of 'blood minerals' and interethnic conflict (Vogel and Radley, 2014).

As the presence of Congolese state representatives at the inauguration ceremony shows, it is not only on the international level that Rubaya is clearly on the map. The presence of important economic and military 'big men' (owning, for example, much of the land on which Rubaya is developing) with ties in Goma as well as in the capital city, Kinshasa, makes this place less 'remote' than it seems and it actually becomes a nodal point in politico-military networks of power and control. At the same time, the presence of state representatives at the ceremony is contradictory. Despite the state's economic and political interest in the town, not even the minimum in terms of state investment has been made in Rubaya's development. As is the case for other mining boomtowns (and any other form of urbanisation) in the region, the Congolese state is rather absent from processes of urbanisation, planning or infrastructure provision. Inauguration ceremonies, performed with grotesque grandeur by Congolese ministers who have never invested one single dollar in projects or places like this, have become painful moments of magnification of state failure and the transfer of the state's legitimacy to other actors, such as international donors (Trefon, 2011). Instead of being the result of a state-led urbanisation process, mining towns like Rubaya are the outcome of a complex interaction of different kinds of agency, in which non-state actors play an important role.

Rubaya's development is not unique in the region. It is one of several urban centres that developed around artisanal mining sites and were transformed into boomtowns during the early 200os. Rising market values of minerals such as cassiterite and coltan attracted many people to dig in the mines; at the same time, violent clashes between different armed groups pushed IDPs into these centres in search of security and a livelihood. Increasing economic activity has transformed the town into a vibrant commercial centre, with its packed houses, its colourful shops and its noisy bars standing in sharp contrast to its rural surroundings. Boomtowns such as Rubaya illustrate the profound reconfiguration of the Kivu landscape in a context of war, violence, repeated displacement and transforming livelihoods. Over the past twenty years, Eastern DRC has become increasingly urbanised, strongly affecting local economies, administrations, landscapes, cultures and identities (Büscher, 2015, 2016).

When places like Rubaya, Kamituga, Numbi or Nyabibwe are mentioned in the academic and policy literature on Eastern DRC, the focus is put on their artisanal mining activity and its role in the broader political economy of natural resources (Cuvelier, 2010; Geenen, 2014; Radley and Vogel, 2015; Vogel and Raeymaekers, 2016). While a lot of attention has been given to local livelihoods 
and the different forms of agency behind the natural resource economies and networks, the dynamics of boomtown urbanisation around these artisanal mines have gone largely unstudied. Instead of the mine itself, mineral extraction and the mine's artisanal miners, this chapter focuses on the town that has developed around them. Its urbanisation will be perceived as a dynamic, transformative process in its own right. In the current Congolese context of a confusing, half-implemented decentralisation law, the expansion of the centre itself becomes a highly political process, involving different state and non-state actors at the local, provincial and national levels. It will be argued that in this political context of war, the establishment, expansion and administrative recognition of these centres represent important political, economic and social resources for multi-scalar alliances of elites, customary authorities, armed groups and the Congolese state in their broader political struggles for power, legitimacy and control. Mining boomtowns represent, for example, significant bases for taxation, electoral politics and ethnic mobilisation.

By presenting mining towns as not only spatial but also analytical starting points from which to study dynamics of power and (violent) control in the Kivu provinces, this chapter speaks to both academic and policy debates. For both debates, this chapter wishes to add an urban dimension to the study of the relationship between conflict and mineral extraction. Academically, the chapter contributes to discussions of urbanity and its 'critical significance' in settings of war (Beall et al., 2011). In Congo's Kivu provinces, urban sites embody 'safe' spatial environments for IDPs or refugees, at the same time being safe havens or strongholds for rebel movements, strategic targets, economic hubs, or hotspots for the humanitarian industry (Büscher, 2016). Further, this chapter adds a missing spatial and particularly urban element to the current debates on violent conflict and the production of public authority in Eastern DRC (Hoffmann and Vlassenroot, 2014). As complex 'laboratories' (Robinson, 2006; Simone, 2004), urban centres embody the spatial, political, social and economic agency of a wide range of actors (state and non-state, formal and informal, public and private, civil and armed). As the chapter illustrates, the distinction between these categories is in reality extremely blurred. With regard to policy debates, the chapter draws attention to the crucial political character of these places as well as of their urbanisation process. Different actors involved in their regulatory frameworks are in fierce competition over power and control, a competition that is often violently mobilised along ethnic lines.

This paper is based on extensive ethnographic fieldwork carried out (by the author and/or by Congolese colleagues) between 2010 and 2017 in Numbi, Nyabibwe (South Kivu) and Rubaya (North Kivu). Fieldwork in these different sites consisted of in-depth interviews with key stakeholders (administrative 
and customary authorities, members of local civil society, heads of mining and commercial associations, representatives of the Congolese security forces and NGO staff), focus-group discussions with different target groups (such as, for example, miners, traders and transporters), social mapping exercises, the consultation of local administrative reports, observational walks and informal discussions.

It is only recently that in academic writings special attention has been paid to the complex relation between mining and urbanisation in Africa. While much has been written on mining and land use/conflicts, mining and mobility, as well as on mining and human settlement patterns, the connection between mining and urban transformation has been largely ignored. Yet both processes make an important contribution to Africa's current transformation of local societies in a global era, as they both produce fundamental demographic, economic, spatial and sociocultural changes. The first attempt to bring together specific studies on the intersection of mining and urbanisation in Africa was made by Bryceson and MacKinnon (2012): from a collection of case studies on Zambia, Tanzania, Ghana, South Africa, Sierra Leone, and the DRC, the editors centred their analysis around what they call 'mineralised urbanisation', or the influence of mineral production cycles and commodity chains on urban growth and settlement patterns at local, regional and national levels. On the one hand, these studies present a clear picture of the diverse settlement trajectories, livelihoods and welfare paths of mining towns; on the other hand, they make an important attempt to examine the current sense of 'mining place' (Bryceson and MacKinnon, 2012, 514).

The issue of mining urbanisation also occupies a central place in the broader theoretical debates on the interaction between global markets and ruralurban dynamics and shifts. In their edited volume, Agergaard et al. (2010) analyse trends of mining urbanisation within the context of the 'frontier', being a region where linkages to global markets are dominated by one particular economic product. Just like other frontier economies (such as cash crop economies linked to the world market), mining frontiers are particularly dynamic spaces characterised by rapid changes in demographic structure, economic basis, occupational opportunities, settlement patterns and land use, where one observes livelihoods being transformed through the establishment of new commercial activities (Agergaard et al., 2010, 3). These dynamics strongly impact rural-urban linkages and processes of urbanisation, metamorphosing 
from remote 'deep rural' to pulsating urban centres of goods and services provision (Bryceson and Mwaipopo, 2010, 158). The concept of frontier urbanisation enables us to investigate mining towns in Eastern DRC as distinctive political, economic and sociocultural spaces (Werthmann and Grätz, 2012) as well as spaces of intense transformation. It is beyond the scope of this chapter to fully engage with the frontier literature on Eastern DRC, but it reinforces our understanding of frontier towns as spaces marked by fierce (often violent) contest over control and authority in the geographic periphery of the state, yet often at its political centre (Raeymaekers, 2014). Further, the literature enables us to see those places as nodes within the political projects of a wide range of actors, such as miners, mining cooperatives, all sorts of local, national and foreign corporations and governments, NGOS, and numerous middlemen, all of them negotiating local governance (Vogel and Raeymaekers, 2016).

A number of researchers has been inspired to ethnographically study the unique environment of these boomtowns and the identities, cultures and lifestyles that they develop (De Boeck, 2001; Werthmann and Grätz, 2012). The case studies of Numbi, Nyabibwe, and Rubaya largely correspond with the findings of this research and of the literature on mining urbanism in general. Attractive because of their 'frontier mystique' (Agergaard et al., 2010) and as centres of rapid in-migration, these settlements have served as 'destinations of desire' (Bryceson and Mwaipopo, 2010, 168), setting in motion dynamics of change, rapid growth and expansion. With a few exceptions, (see, for example, Büscher et al., 2014; De Boeck, 2001; Kabamba, 2012; Vlassenroot and Raeymaekers, 2004; Vwakyanakazi, 1992), mining urbanisation in the DRC has not been explicitly documented. Yet the academic interest in artisanal mining in the DRC is well developed, and several researchers have extensively studied the ways in which, in the context of state crisis and civil war, artisanal mining has become a livelihood strategy for very different civil and military actors (see, for example, Ansoms and Marysse, 2011; Bashwira, 2017; Geenen, 2013). The Kivu provinces, where this research is located, are extremely rich in natural resources such as gold, colombo-tantalite (coltan) and cassiterite (tin). At the same time, these provinces have been characterised by a protracted situation of violent conflict. The dwindling power and role of formal state institutions have been the result of a profound economic and political crisis that was already set in motion in the mid-199os at the end of the Mobutu era. A civil war that started in the second half of the 1990s has evolved over the last 20 years into a complex jumble of dynamics of violence and conflict and a proliferation of armed groups in the Kivu provinces. During the different episodes of the war, mining towns have been strongly influenced by dynamics of forced displacement, violence and militarisation. The massive arrival of Hutu refugees in 1994, fleeing Rwanda 
(after the political changes following the end of the genocide), strongly impacted on such towns' demographic composition, local economies and political constellations. As has been extensively documented, these 1994 dynamics set in motion the start of a series of violent conflicts in the broader region (see, for example, Turner, 2007), and throughout the war towns like Numbi and Nyabibwe have been an operational ground for multiple armed groups.

Dynamics of violence and conflict have produced social transformation and generated a number of important shifts in the socio-economic sphere (Vlassenroot and Raeymaekers, 2004, 14). These shifts, with regard to issues such as access to land and the structure of public authoritym for example, should not be explained as temporary effects of a context of violence and war but as elements of a general transformation of local society. In earlier works I have argued that rural-urban shifts and the emergence of boomtowns in the Kivu provinces should be understood as a spatial aspect of this transformative power of violent conflict (Büscher, 2011, 2016). This transformation of peripheral rural mining sites into urbanised centres of (largely informal) accumulation and survival has resulted in a profound socio-economic, spatial and political reorganisation of local society.

The thriving forces behind the fast expansion of these mining agglomerations are multiple, and a combination of structural processes and people's agency. Like booming mining towns elsewhere, not only does the arrival of large groups of artisanal miners gave a considerable boost to local economic activity (Cuvelier, 2010; Walsh, 2003; Werthmann, 2003), these boomtowns also serve as a place of refuge for people seeking to rebuild their lives after having been marginalised in their communities of origin (Fisher, 2007; Grätz, 2009; Werthmann, 2009). Kivu's mining towns have attracted important numbers of rural poor and urban unemployed in search of their fortunes, but at the same time the ongoing violence has pushed large parts of the rural population to the same centres in search of physical security (Vlassenroot and Raeymaekers, 2004, 143). ${ }^{3}$ Mining towns often form attractive 'safe havens' for refugees (coming from Rwanda) and IDPs (coming from Kivu's rural hinterlands), who settle in camps or in the town itself. The more these centres grow and develop, the more miners and IDPs have been followed by an influx of all kinds of other 'migrants' seeking to integrate into and invest in these emerging semi-urban

3 Urban centres providing a haven in civil conflicts is fairly common (Beall et al., 2011). The urban features of inclusiveness, freedom, global connections and cosmopolitism mark the attractiveness of cities. In the Kivu provinces, urbanised areas have become attractive poles for IDPs because of their ethnically more diversified demographic profiles (compared to surrounding villages), the higher presence of NGOs or humanitarian agencies, and the higher presence of Congolese (as well as UN) security forces. 
economies. This has led (in some cases more than others) to the creation of an ethnically and economically diverse demography, the development of new markets, increased circulation of money and goods and the spontaneous development of infrastructure and services. Traders, transporters, hotel and bar managers, butchers, pharmacists, etc. gradually settle and start their businesses in these highly populated spaces. Although much of the mining extraction itself is largely carried out by men, these boomtowns are far from being a 'man's world', and women play important roles in local economies and occupy a variety of positions (Bashwira et al., 2014). ${ }^{4}$ In a short time, these former villages transform into booming agglomerations with an increasingly 'urban' character (Büscher et al., 2014; Mususa, 2012). What makes these places 'urban' or 'semiurban' is not only a matter of demographic size and density; it is also a matter of demographic composition, economic accumulation, livelihood diversification, public service provision, settlement patterns and political organisation (Dobler, 2009; Werthmann, 2009).

A fact that is often overlooked in academic debates is that the process of mining urbanisation is not only a demographic, administrative, spatial and economic process, but is a political process as well. This chapter, analysing mining boomtowns in a context of violent conflict, will contribute to the understanding of the politics of mining urbanisation and boomtown urbanisation in general. Through a long history of political and economic crisis and war, mining urbanism came to involve particular types of stakeholders-formal and informal, civilian and military. This particular setting generates distinctive patterns of urbanisation, settlement, governance and livelihoods, generating an urbanisation process that is often of a highly unstable and conflictual nature (Büscher, forthcoming).

Further, this urbanisation process is inevitably interwoven with agendas of political, military and ethnic mobilisation. To recognise mining urbanisation as a political process, it is important to understand the mining town as the spatial arena of political constellations and to understand the process of urbanisation as a part of political mechanisms. A case illustrative of the political aspect of the urbanisation of these boomtowns is the process of their administrative transformation from the status of a 'centre' or village, towards the status of a 'commune'. According to the decentralisation law of the DRC, agglomerations

4 A study undertaken by the gender section of MONUSCo in 2010 in six Congolese provinces found that women mostly work in the processing of mineral tailings (e.g. sieving, sorting, transporting and washing), followed by activities related indirectly to mineral exploitation (e.g. as small goods traders, housewives or prostitutes) (MONUSCO, 2010, cited in Bashwira, 2017, 109). 
change administrative status according to their demographic statistics. With, for example, more than 20,000 inhabitants, a village can be recognised as a 'commune'. From our cases, it will become clear how this process is more than an administrative mechanism: it is a highly political issue, creating fierce power contestation and conflicts.

\section{The Case of Nyabibwe and Numbi (Kalehe, South Kivu)}

Kalehe territory in South Kivu has served as a case study to look at a variety of conflict dynamics that have become hot topics in the literature and in knowledge production with regard to the war in Eastern DRC, such as the proliferation of armed groups (Hoffmann and Vlassenroot, 2014), the struggle over citizenship (Vlassenroot, 2013), land issues (Ansoms et al., 2012) and the political economy of natural resources (Jackson, 2006; Cuvelier, 2010). Until the present, the region has been characterised by the mobilisation of armed groups, strong ethnic tensions, violent struggles over public authority and militarised land conflicts. In the early years of the new millennium, during the $\mathrm{RCD}$ rebellion ${ }^{5}$ that coincided with the global boom in demand for coltan and cassiterite, several boomtowns emerged around artisanal mining sites in Kalehe. Both Nyabibwe and Numbi have experienced spectacular growth over the last two decades, transforming from small villages into extended 'urbanised' agglomerations.

Nyabibwe, with approximately 25,000 inhabitants in $2015,{ }^{6}$ is situated on the main road that runs along the shores of Lake Kivu and connects the two main cities in the Kivu region: Goma (capital city of North Kivu province) and Bukavu (capital of South Kivu province). The town emerged in proximity to the Kalimbi mines, which were exploited from the mid-1970s on, in an industrial manner. From the end of the 1980 s, detrimental economic nationalisation policies in Zaire, and further economic decay throughout the 199os, resulted in the gradual informalisation of mineral extraction. The 'big boom' occurred in 2000-01, when the war pushed, and global mineral prices attracted, thousands of miners to the town, resulting in a quadrupling of its population. The town distinguishes itself from its rural surroundings by its 'cosmopolitan' character, including the different ethnic groups to be found in the region. Hutu comprise

5 Rassemblement Congolais pour la Democratie (RCD), a Rwandan and Ugandan backed rebel movement that controlled large parts of Eastern Congo between 1998 and 2004. For more information see Tull (2003) and Vlassenroot and Raeymaekers (2004).

6 Statistics provided by the local health centre of Nyabibwe. 
the largest group, and other well-represented communities are Havu, Tembo, Bashi and Tutsi. A historical friction between, on the one hand, Hutu and, on the other, Tembo and Havu has been reinforced by dynamics of conflict and militarisation. Administratively, Nyabibwe is governed by two layers of authority: customary (traditional) authority in the form of a customary chief, and state (administrative) authority in the form of a chef du poste. The former is traditionally the realm of the Tembo and Havu community, while the latter is locally elected and thus represents the Hutu majority. In light of regional (violent) ethnic politics, this fragmented leadership has been often conflictual. Mining activities have had an important impact on the local leadership; the mining cooperatives Coopérative Minière de Kalimbi (СOMIKA) and Coopérative Minière du Bien-Être Communautaire de Kalehe (COOMBEcKA), who control and govern these activities, have an important stake in local politics, and are in their turn strongly influenced by regional and national elites in the larger cities of Goma and Bukavu (Cuvelier, 2013).

Numbi, with an estimated number of inhabitants between 10,000 and 11,000, ${ }^{7}$ is situated in the highlands (Hauts Plateaux) of Kalehe, some $30 \mathrm{~km}$ from the main road that runs along Lake Kivu. Compared to Nyabibwe (which is located on the main road) and because of almost non-existent road access (most of the time it inaccessible to cars), Numbi is an extremely isolated place. It is surrounded by huge pasture concessions, owned by influential Tutsi elites that emerged during the RCD rebellion (1998-2004). As we observe in other mining towns, the involvement of such politico-military elites, connected to local, provincial, national and even trans-border power networks, strongly contests the 'isolated' nature of the place. Administered under the status of a 'village', it is headed by a customary chief from the Tutsi community and a state authority from the Tembo community. As is the case in Nyabibwe, a fierce conflict between these two layers of authority over the control of the town (and crucial mechanisms such as land distribution or taxation revenues) has known very violent episodes. During the RCD period, as part of the group's efforts to establish its parallel administration, Numbi was administratively 'upgraded' and came under the control of a Tutsi chief close to the rebel movement. In 2006, after the peace process and the country's reunification, this chief was replaced by a Hutu chief. In 2012, the former Tutsi chief, by influencing provincial political and ex-rebel elites in Bukavu, regained control thanks to the appointment of his own brother as the new chief. The local Hutu population, who perceived

7 In 2014, the figure of 8900 inhabitants was provided by the local health centre. According to Numbi's local authorities, the actual number was around 11,000 or 12,000 inhabitants (interviews with village chief and chef de poste, Numbi, April 2014). 
this as an orchestrated Tutsi coup d'état, strongly opposed his rule, a situation which created strong ethnic tensions. ${ }^{8}$ Further, Numbi is known for its violent land conflicts, which are being significantly politicised by elites (urban-based elites in Goma, for example) through the political and military connections of the landowners (Ansoms et al., 2012). As was equally the case for Nyabibwe, mining activities in the nearby pits had been informalised since the 9os, and were very small scale. Also similarly, a mining boom occurred at the turn of the new millennium.

Much of its urbanisation process initially unfolded in an organic, spontaneous and unplanned way, yet various actors have increasingly tried to incorporate the process, as a spatial mechanism of control, into their own political or economic ambitions. In Numbi, local elites have, on the one hand, tried to invest in a minimum of infrastructure (to anticipate an administrative upgrade within the decentralisation process - see below). On the other hand, rumours circulate about other elites at the provincial and national level blocking investments in urban expansion (such as the road, which is in a perpetual state of disrepair), to prevent external actors, including the Congolese state, from interference. $^{9}$

Numbi and, to a lesser extent, Nyabibwe are situated in areas that have experienced significant levels of armed mobilisation for at least two decades. Both 'autochthonous' militia (such as Mai-Mai groups in the second Congo war and Raia Mutomboki factions thereafter) as well as different trajectories of Congolese Hutu mobilisation (branches of the Coalition of Congolese Patriotic Resistance (PARECO) and, more recently, different Nyatura groups) deploy a degree of influence to these urban centres and their surroundings. Violent and militarised struggle for control over these centres of course needs to be understood in the light of their strategic significance as mining towns. From 2010 onwards, Nyabibwe was selected as one of the first pilot cases for the 'traceability process' organised by the International Tin Research Institute (ITRI). ${ }^{10}$ In Numbi, which is far less state controlled and more isolated, armed groups like Nyatura were, until 2012 involved in taxation mechanisms applied to

8 For example, the local chief of a nearby village, put in place by the Tutsi chief, was murdered a couple of days after his appointment, allegedly by members of the armed Hutu franchise group Nyatura ('hit hard' in Kinyarwanda). Interview with an entrepreneur (Numbi, April 2014); interview with a mineral buyer (or middleman (négotiant)) (Numbi, April 2014). See also Pole Institute (2012).

9 Focus group with mineral buyers/middlemen (négociants) (Numbi, April 2014); interview with an entrepreneur (Numbi, April 2014).

10 Since February 2018 known as International Tin Association (ITA) Ltd. For more information on this supply chain traceability initiative, see Verbrugge et al. (2011) and Geenen (2016). 
mining incomes, although not present in the mines themselves. Until the present day, despite the different disarmament initiatives, the circulation of arms remains an important challenge, and local, everyday conflicts often escalate as violence remains an important means in daily livelihood strategies. ${ }^{11}$

The urbanisation process of these towns was further shaped by the vast influx of internally displaced people. In both Nyabibwe and Numbi, IDPs settled within the mining agglomeration. Many of them went to work in the mines, others integrating into other economic sectors. In Nyabibwe, for example, IDPs coming from Masisi introduced 'new' commercial activities such as the exploitation of small cafeterias where people can consume milk and a small breakfast. Apart from mining, inhabitants of Nyabibwe and Numbi are engaged in a number of secondary activities, such as small trading in staple goods, transport, trading in wood, and — of course —in the proliferation of very lucrative activities catering for the food and entertainment needs of the mine workers. With a purchasing power far in excess of farmers in the surrounding countryside, the presence of miners in these towns has resulted in the emergence of a highly profitable 'entertainment infrastructure' and a sharp increase of the numbers of bars, cinemas and restaurants since the start of the new millennium. ${ }^{12}$ It is this proliferation of secondary activities (butchers' shops, hairdressers, other shops), services (pharmacies, hotels) and entertainment infrastructure (cinemas, bars) and the large diversity of traded products that shape these mining towns' semi-urban character. As local traders in Nyabibwe told me: 'today in Nyabibwe one can find almost everything one can find in the city'..$^{13}$ One example of an economic sector that spectacularly expanded due to the process of mining urbanisation was the transport sector. Operating motorcycle taxis is a lucrative livelihood option for many youngsters and IDPs, as well as an attractive market for investment because of its high returns. ${ }^{14}$ This economic transformation went hand in hand with a material reconfiguration of the villages' landscapes, increasingly evolving towards 'urbanised' settlements (with 'durable' housing materials, multi-storey houses and relatively extensive infrastructure).

The expansion of these dynamic mining towns did not only attract armed groups, miners, traders and ID Ps; it also encouraged the Congolese state to settle at these sites, presenting — as they do-interesting economic and political

11 Focus group discussion with miners (Numbi, April 2014); interview with a village chief (Numbi, April 2014); author's own observations.

12 Interview with the manager of a Nganda or 'popular bar' (Nyabibwe, May 2013).

13 Focus group with traders (Nyabibwe, May 2013).

14 Focus group with motorcycle riders and interview with an FEC representative (Nyabibwe, May 2013). Since the purchase price of a motorcycle in Goma is only USD 1,500, not only urban-based elites but also local miners and middlemen can easily invest in this 'market'. 
opportunities. In Nyabibwe, from around 2005 onwards, state offices increasingly installed themselves in the town, opening local branches of the Divisions of Hygiene, Tourism, Urbanisation, etc. In fact, these branches are often no more than a barely equipped 'office' (often a small wooden room) run by badly paid staff. The official discourse of 'better coordinating and organizing the town's expansion and urbanisation' 15 masks the real desires to get a piece of the massive cash flows and financial interests generated by these boomtowns. In Numbi, not only established elites but also new big men (most of them with high ranking positions in the Congolese army) have heavily invested in real estate. Most of the houses and hotels are owned by colonels, captains, and others in the Armed Forces of the Democratic Republic of the Congo (FARDC) investments that somehow 'assure' the local population of a stable future. ${ }^{16}$

In 2013, in the context of the decentralisation reforms, ${ }^{17}$ Nyabibwe was in the process of being recognised as a 'commune' in a decree from the central government. On June 13, the First Minister of the central government and the Minister of the Interior signed the decree, fixing the geographic limits of the agglomeration. ${ }^{18}$ The transformation of Nyabibwe into a commune is the direct consequence of its growth. The law, on paper, grants an important degree of autonomy to the decentralised entity, in terms of its governance of human, economic and financial resources (Englebert, 2012). One consequence of this shift was that the customary authorities would lose administrative control to an elected state agent or a 'bourgemestre'. Afraid he would lose the right to collect fees, taxes and royalties on mining and other commercial activities in the most important economic centre of his chieftaincy, the customary chief undertook various steps to preserve his influence. Büscher et al. (2014) have described in detail how, by for example influencing 'connected' politicians on the provincial level or by strategically selling off his land and intervening in the local political economy of the town's mining activities, the chief's strategies of maintaining power and authority have laid the basis for further local political

15 Interview with an official from the Division of Urbanisation and Habitat (Kalehe, May 2013).

16 Interview with an entrepreneur (Numbi, April 2014).

17 These reforms were launched in 2006 to improve governance and accountability, undermine predation, corruption, and personal rule, bring government closer to the people, and promote local development. However, as Englebert and Kasongo Mungongo $(2016,1)$ have argued: 'As of 2014, despite some regional variations, Congolese decentralisation had instead increased the degree to which the state extracts the resources and incomes of its citizens'.

18 Décret $n^{\circ}{ }_{13} / 029$ du 13 juin 2013 conférant le statut de ville et de commune à certaines agglomérations de la province du Sud-Kivu. 
conflicts. In the meantime, the decentralisation law has been suspended. Since 2014, Numbi has been waiting to also be granted the status of a 'commune', yet until this day this process has not been further implemented as local elections are repeatedly postponed. As I will further demonstrate through the case of Rubaya, this half-implemented decentralisation law creates confusion, offering room for manoeuvre that enables the state and other actors, such as economic and military big men, to exercise their power over these places. Urbanisation is in itself a process characterised by contestation; these political mechanisms have strongly reinforced these conflicts.

Rubaya, a town currently estimated to have a population of $70,000,{ }^{19}$ is situated in Masisi (North Kivu), a region known for its violent history of identity politics. Originally, Rubaya emerged around a transit point for Rwandan labourers 'exported' into Congo (Hutu and Tutsi; today locally referred to as 'Banyarwanda') by the Belgian colonisers in the 1930 s and 40 s to sustain the colonial plantation economy in the Masisi highlands. Ethnic tensions between these Banyarwanda and the so-called autochthonous populations (status claimed by people from the Hunde and Tembo community) rose in the aftermath of the Rwandan genocide, when hundreds of thousands of Hutu sought refuge in the Kivu provinces. Their arrival in Rubaya caused many Tutsi and Hunde to flee, ${ }^{20}$ and in parallel with the wider region had a general destabilising effect.

Rubaya knew its real 'boom' phase during the RCD period, when coltan had been discovered three kilometres from the town's centre. Local big men from the Hutu community saw their positions reinforced by the political-economic Hutu elite that was installed in the North Kivu province under the provincial governor Eugène Serufuli, controlling the main administrative posts and key economic sectors. ${ }^{21}$ In this period of rapid expansion, several neighbourhoods were constructed and the reconfiguration of Rubaya's landscape was also visible in the transformation of wooden shacks into constructions in more durable housing materials and the erection of multi-storey buildings. In 2001 Rubaya was administratively recognised as a commercial centre and a chef de

\footnotetext{
19 Activity Report of a local health centre; local electoral inscription centre.

20 Interview with a former chef de poste (Rubaya, June 2017).

21 Focus group discussion with Rubaya mineral buyers and middlemen (négociants) (Goma, May 2016).
} 
centre was appointed from the provincial administration. Eugène Serufuli himself invested in the centre with the installation of a radio mast. ${ }^{22}$

The National Congress for the Defence of the People (CNDP) rebellion introduced a new phase of military conflict in Rubaya, with heavy clashes between the CNDP and the Congolese army as well as the PARECO armed group. As one of the CNDP's strongholds, mining activities were controlled by the Congress and the town of Rubaya was governed through a parallel rebel administration, which 'elevated' it to the administrative status of a 'cite' (resulting, amongst other things, in more power and autonomy for rebel-appointed officials over customary authorities). ${ }^{23}$ Even today, armed groups such as Nyatura and the Alliance of Patriots for a Free and Sovereign Congo (APCLS) ${ }^{24}$ remain active in Rubaya's immediate proximity (United Nations Security Council, 2015). This complex history of violent conflict, in which the town has occupied different positions, from rebel stronghold to a safe haven for IDPs, has generated a process of urbanisation that is highly militarised. Now that armed groups are no longer physically present in the town itself, a heavy presence from police and soldiers has taken over. ${ }^{25}$ Rubaya, just like Numbi, suffers from a vast proliferation of arms among its inhabitants. This results in a constant fear of violence and casualties in the case of (even very banal) conflicts. ${ }^{26}$ Rumours regarding the creation of a new rebel movement in Rubaya are illustrative of this volatile situation. ${ }^{27}$

More than Numbi and Nyabibwe, Rubaya's evolution has been marked by processes of forced displacement and an influx of IDPs and refugees. Through the different phases of the violent conflict, IDPs and refugees have installed themselves in camps around the centre and in the centre itself. In 2016, the last ID P camp inside the town was closed by the provincial governor and today two camps remain, at four and seven kilometres from the town, respectively. Their

22 Interview with a teacher and interview with a priest (Rubaya, June 2017).

23 Interview with a former chef de poste (Rubaya, June 2017).

24 Essentially Hunde; emerged in 2008. Like many of these other militias, it mobilised its forces on the basis of popular resistance to the return of Tutsi refugees, the defence of traditional Hunde land rights, and defence against the expansion of the influence of Banyarwanda in Masisi territory.

25 This presence is not constant however, and fluctuates with periods of tension.

26 See, for example, Radio Okapi (2016) 'Nord-Kivu : 9 blessés dans une fusillade à Masisi', https://www.radiookapi.net/2016/o1/14/actualite/societe/nord-kivu-9-blesses-dans-unefusillade-masisi (accessed on 1 November 2017).

27 Radio Okapi (2014) 'Nord-Kivu : soupçons d'une présumée reconstitution du M23 à Rubaya', https://www.radiookapi.net/actualite/2014/08/30/nord-kivu-soupcons-dune-presumee-reconstitution-du-m23-rubaya (accessed on 1 November 2017). 
inhabitants (mainly Hutu) represent a pool of cheap labour for employment in cultivating the land surrounding Rubaya. ${ }^{28}$

Rubaya's big man is Robert Habinshuti Seninga - a Hutu and a muchdiscussed figure in the region's recent history. As one of former governor Serufuli's close allies during the RCD period, he has remained in power and has continued to use his influence (Cuvelier et al., 2014). He is the president of COOPERAMMA, the mining cooperative in Rubaya, and just like in Nyabibwe and Numbi, the cooperative is a major player in local governance. It has an important stake in local politics and is itself significantly influenced by regional and national elites (Cuvelier, 2013). One several occasions COOPERAMMA has engaged in the physical development of the town. In 2014, the organisation bought a large piece of land, baptised it quartier COOPERAMMA, and put together its own commission (with Seninga himself at its head) to parcel it out. In 2015, under the same commission, two more neighbourhoods were developed on land belonging to a FARDC general. ${ }^{29}$ These neighbourhoods are generally referred to as the 'best developed' in town, with more or less good roads, a health centre and spacious parcels. Further, COOPERAMMA also regularly invests in road repairs and maintenance, and in 2014 it installed a small hydropower plant to provide the town with electricity (a project that largely failed, partially because the Congolese state imposed heavy taxes on the electricity produced). ${ }^{30}$ COOPERAMMA's involvement in Rubaya's development is again illustrative of an urbanisation process that unfolds outside formal state planning and is the outcome of the agency of different non-state actors. Furthermore, the involvement of big men as key actors in this development illustrates that it is a political process, used in strategies of legitimacy and control. The position of these key actors within political and military networks reaching the provincial and national levels reinforces this political character. This is further illustrated in the struggle for administrative control over the town in the current context of the controversial decentralisation process.

Rubaya is a town with a mixed ethnic profile, with Tutsi, Hunde, Tembo, Shi and Kano, but with a strong Hutu dominance. With its considerable size and number of inhabitants, Rubaya is in the process of becoming a 'commune' in the context of the decentralisation law. Although customary power is less strong in Rubaya than it is, for example, in Nyabibwe, this would still influence

\footnotetext{
28 Interview with a customary chief (Rubaya, June 2017).

29 Focus group discussion with Rubaya middlemen (négociants) (Goma, May 2016); interview with a COOPERAMMA representative (Rubaya, June 2017).

30 Focus group discussion with Rubaya mineral buyers/middlemen (négociants) (Goma, May 2016).
} 
the balance of power in the area. Within the complex history of violent conflict in Masisi, this balance of power is heavily coloured by the continuous power struggles between the so-called autochthonous population and the Banyarwanda, and internally between the Hutu and Tutsi communities. In the first place, it was Rubaya's chef de poste (a Hutu), who made the 'commune' request to the provincial government, believing he would be appointed as the head of the new administrative entity. ${ }^{31}$ The demand was further encouraged by the town's economic Hutu elite. ${ }^{32}$ However, the 'postes de territoires' were being abolished in North Kivu, and shortly after any further implementation of the decentralisation law was suspended. In the context of this administrative vacuum, a 'provincial delegate' was appointed by the provincial governor. To this day, this delegate, Bihami Serkali (a former administrator from the RCD period) is the only official administrative representative in Rubaya, yet he has very little legitimacy given his unclear mandate and his equally unclear juridical status. Because Serkali is a close ally of Seninga, his appointment is generally viewed as a result of Seninga's political lobbying efforts and mechanisms of control. ${ }^{33}$ Especially among the local Hunde and their customary chief, there is strong resentment regarding his appointment, as they perceive it as a Hutu strategy to seize control over resources, such as land and taxes, from the customary authorities. ${ }^{34}$

These current political struggles over mining towns point to a number of dimensions of mining urbanisation in a context of violent conflict that are of crucial academic as well as policy importance.

First of all, they underline the fact that these places represent strategic nodes in the dynamics of development and accumulation, as well as in the dynamics of political and military control. These towns attract huge numbers of people from rural as well as urban environments in the Kivu provinces and they grow at great speed. As attractive poles of investment and livelihood diversification,

\footnotetext{
31 Interview with a former chef de poste (Rubaya, June 2017).

32 Interview with a representative of the Federation of Economics and Commerce (FEC) (Rubaya, June 2017).

33 Focus group discussion with miners (Rubaya, June 2017); focus group discussion with Rubaya mineral buyers/middlemen (négociants) (Goma, May 2016). We see the same dynamics in other urbanising and fast-growing towns in North Kivu, including in Kitchanga (Mathys and Büscher, forthcoming).

Interview with a customary chief (Rubaya, June 2017).
} 
for researchers as well as for policy makers, it is crucial to look at these places, given their transformative power in processes of development, social change and stability. The 'urban' has for a long time been largely ignored in academic and policy studies on conflict and development in Eastern Congo. Secondary urban centres in particular have received only minor attention, yet as this research demonstrates, they may play a central role in dynamics of conflict and peace. An urban reading of wartime economic, spatial as well as political transformation is necessary if we are to understand current processes of ruralurban development as well as the production of order and public authority in Eastern DRC.

Second, what this chapter has demonstrated and what should further inform academic and policy engagement with this topic is that these boomtowns represent attractive resources to tap into for a wide range of actors. Mining urbanisation involves intense interaction between an extremely varied set of actors (political, economic, humanitarian, civil, military, formal, informal, state and non-state) and offers extensive room for manoeuvre for their diverse agencies. This applies not only to the rural migrants or displaced people seeking security and income opportunities, but also to armed groups integrating into ethnic groups for the purpose of violent mobilisation, or to the Congolese state profiting from tax benefits, or to political and economic elites tapping into economic resources such as land or mining activities, or political resources such as electoral bases. These attractive spaces of rural-urban transformation display interesting governance arrangements between customary authorities, state institutions, state and non-state military actors, big men and IDPS.

Third, given the fact that these governance arrangements are part of multiscalar alliances involving actors in Goma or Kinshasa or abroad, the socioeconomic and political dynamics emerging from mining urbanisation are less local than they may appear at first sight. Many of these alliances are the outcome of a historical process of armed conflict, state fragmentation and the ethnic logics of protection. ${ }^{35}$ In ethnic struggles for access to political and economic resources, these political and military alliances are easily mobilised. In a setting where mining cooperatives have major stakes in urban planning and urban governance, the local regulatory framework of this boomtown process is influenced by the political stakes of external elites. Conflicts arising from the transformation of rural villages into mining boomtowns are as such easily politicized at different levels, reinforcing the towns' larger regional influence. This has influenced the political character of mining urbanisation. The case studies of Numbi, Nyabibwe and Rubaya have underlined the importance of 
understanding the rapid development of these towns not only as a demographic, economic and spatial process, but as a political process as well.

The effects of the decentralisation reforms that change the administrative status of these boomtowns uncover broader violent struggles for power and control, often fought along ethnic lines. They also illustrate that interventions in these places can trigger existing tensions and render them more violent. To capitalise upon the transformative capacity of these places, a profound understanding is indispensable regarding their position and role in the complex political geography of the Kivu region.

\section{Acknowledgements}

This research has been carried out with the financial support of the Flanders Research Foundation. The data was collected in collaboration with our Congolese partners from APC (Action pour la Paix et la Concorde) in Bukavu. I would like to thank Christoph Vogel for his critical input on this paper.

\section{References}

Agergaard, J, N. Fold and K. Gough (eds.) (2010), Rural-urban dynamics: Livelihoods, mobility and markets in African and Asian Frontiers (London: Routledge).

Ansoms, A., K. Claessens and E. Mudinga (2012) 'L'accarpement des terres par des élites en térritoire de Kalehe, RDC', in F. Reyntjens, S. Vandeginste and M. Verpoorten (eds.) Afrique des Grands Lacs, Annuaire, 2011-2012 (Paris: L'Harmattan), pp. 205-226.

Ansoms, A. and S. Marysse, (2011) Natural resources and local livelihoods in de Great Lakes Region of Africa; a political economy perspective (Basingstoke: Palgrave Macmillan).

Bashwira, M.R. (2017) Navigating obstacles, opportunities and reforms, woman's lives and livelihoods in artisanal mining communities in eastern DRC, $\mathrm{PhD}$ Dissertation (Wageningen: Wageningen University), http://edepot.wur.nl/4139o1.

Bashwira, M.R., C. Cuvelier, T. Hilhorst and G. Van der Haar (2014) 'Not only a man's world: women's involvement in artisanal mining in eastern DRC', Resources Policy, 40, pp. 109-116, DOI: 10.1016/j.resourpol.2013.11.002.

Beall, J., T. Goodfellow and D. Rodgers (eds.) (2011) Cities, Conflict and State Fragility, Working paper, 85 (London: LSE), https://www.files.ethz.ch/isn/136064/wp852.pdf (accessed on 28 May 2018). 
Bryceson, D. and D. Mackinnon (2012) 'Eureka and beyond: mining's impact on African urbanisation', Journal of Contemporary African Studies, 30(4), pp. 513-537.

Bryceson, D. and R. Mwaipopo (2010) 'Rural-urban transitions in Tanzania's northwest mining frontier', in J. Agergaard, N. Fold and K. Gough (eds.) Rural-urban dynamics: Livelihoods, mobility and markets in African and Asian Frontiers (London: Routledge), pp. 158-173.

Büscher, K. (2018) 'War, displacement and rural-urban transformation: Kivu's boomtowns, Eastern D.R. Congo' (manuscript submitted for publication).

Büscher, K. (2016) 'Reading urban landscapes of war and peace: the case of Goma, DRC', in A. Björkdahl and S. Buckley-Zistel (eds) Spatializing Peace and Conflict; Mapping the production of places, sites and scales of violence (Basingstoke: Palgrave Macmillan), pp. 79-97.

Büscher, K. (2015) 'On-Going Crisis in Eastern DR Congo: The Need for an Urban Perspective', Urban Africa, 11 August, https://www.urbanafrica.net/urban-voices/ on-going-crisis-in-eastern-d-r-congo-the-need-for-an-urban-perspective/(accessed on 5 November 2017).

Büscher, K. (2011) Violent conflict, state weakening and processes of urban transformation in the Eastern Congolese periphery; the case of Goma, unpublished $\mathrm{PhD}$ dissertation (Ghent: Ghent University), https://biblio.ugent.be/publication/2092391/ file/4335807 (accessed on 28 May 2018).

Büscher, K., J. Cuvelier and F. Mushobekwa (2014) 'La dimension politique de l'urbanisme minière dans un context fragile de conflict armé; le cas de Nyabibwe', in M. Verpoorten, S. Vandeginste and F. Reyntjens (eds.) Annuaire de l'Afrique des Grands Lacs, 2013-2014 (Paris : L'Harmattan), pp. 243-268.

Cuvelier, J. (2013) 'Conflict Minerals in Eastern Democratic Republic of Congo: planned interventions and unexpected outcomes', in T. Hilhorst (ed.), Disaster, Conflict and Society in Crisis (London: Routledge), pp. 132-148.

Cuvelier, J. (ed.) (2010) The complexity of resource governance in a context of state fragility: the case of Eastern DRC, Report International Alert (London: International Alert) http://www.international-alert.org/publications/complexity-resource-governance -context-state-fragility-case-eastern-drc (accessed on 6 November 2017).

Cuvelier, J., S. Van Bockstael, K. Vlassenroot and C. Iguma (2014) Analyzing the Impact of the Dodd-Frank Act on Congolese Livelihoods, CPPF Conflict Prevention and Peace Forum Report (New York: SSRC), https://biblio.ugent.be/publication/5766410/ file/5766411.pdf (accessed on 6 November 2017).

De Boeck, F. (2001) 'Garimpeiro Worlds: Digging, Dying and "Hunting” for Diamonds in Angola', Review of African Political Economy, 28(9o), pp. 549-562, DOI: $10.1080 / 03056240108704565$. 
Dobler, G. (2009) 'Oshikango: The Dynamics of Growth and Regulation in a Namibian Boom Town', Journal of Southern African Studies, 35, pp. 115-131, DOI: 10.1080/03057070802685601.

Englebert, P. (2012) 'Incertitude, autonomie et parasitisme : les entités territoriales décentralisées et l'état en République Démocratique du Congo', Politique africaine, 125, pp . 169-188, DOI: 10.3917/polaf.125.0169.

Englebert, P. and E. Kasongo Mungongo (2016) 'Misguided and Misdiagnosed: The Failure of Decentralization Reforms in the DR Congo', African Studies Review, 59(1), pp. 5-32, DOI: 10.1017/asr.2016.5.

Fisher, E. (2007) 'Occupying the margins: labour integration and social exclusion in artisanal mining in Tanzania', Development and Change, 38(4), pp. $735^{-760}$, DOI: 10.1111/j.1467-7660.2007.00431.x.

Geenen, S. (2016) African Artisanal Mining from the Inside Out; Access norms and power in Congo's Gold Sector (London: Routledge).

Geenen, S. (2014) 'Dispossession, displacement and resistance: artisanal miners in a gold concession in South-Kivu, Democratic Republic of Congo', Resources Policy, 40, pp. 90-99, DOI: 10.1016/j.resourpol.2013.03.004.

Geenen, S. (2013) 'Who seeks, finds: how artisanal miners and traders benefit from gold in the Eastern Democratic Republic of Congo', European Journal of Development Research, 25, pp. 197-212, DOI: 10.1057/ejdr.2012.19.

Grätz, T. (2009) 'Moralities, risk and rules in West African artisanal gold mining communities: A case study of Northern Benin', Resources Policy, 34(1), pp. 12-17, http:// hdl.handle.net/11858/00-001M-00oo-0011-92 $\mathrm{C}_{3}-8$.

Hoffmann, K. and K. Vlassenroot (2014) 'Armed groups and the exercise of public authority: the cases of the Mayi- Mayi and Raya Mutomboki in Kalehe, South Kivu', Peacebuilding 2(2), pp. 202-220, DOI: 10.1080/21647259.2014.910384.

Jackson, S. (2006) 'Sons of Which Soil? The Language and Politics of Autochthony in Eastern D.R. Congo', African Studies Review, 49(2) pp. 95-123, DOI: 10.1353/ arw.2006.0107.

Kabamba, P.(2012) 'A tale of two cities: urban transformation in gold-centered Butembo and diamond-rich Mbuji-Mayi, Democratic Republic of the Congo', Journal of Contemporary African Studies, 30(4), pp. 669-685, DOI: 10.1080/02589001.2012.724870.

Matthys, G. and K. Büscher (2018) 'Violent conflict, displacement and urbanisation in Eastern Congo: the case of Kitchanga' Journal of Eastern African Studies, 12 (2), pp. 232-253.

Mususa, P. (2012) 'Mining, welfare and urbanisation: the wavering urban character if Zambia's Copperbelt', Journal of Contemporary African Studies, 30(4), pp. 571-588, DOI: 10.1080/02589001.2012.724873.

Pole Institute (2012) Numbi: Entre richesses potentielles et carences réelles de l'Etat en territoire de Kalehe/Sud Kivu (Goma : Pole Institute, Institut Interculturel pour la 
paix dans la Région des Grands Lacs), http://pole-institute.org/article/numbientre-richesses-potentielles-et-carences-réelles-de-l'etat-en-territoire-de-kalehesud (accessed on 6 November 2017).

Radley, B. and C. Vogel (2015) 'Fighting Windmills in Eastern Congo? The ambiguous impact of the "conflict minerals" movement', The Extractive Industries and Society, 2(3), pp. 406-410.

Raeymaekers, T. (2014) Violent Capitalism and Hybrid Identity in the Eastern Congo: Power to the Margins (New York: Cambridge University Press).

Raeymaekers, T. (2010) 'Protection for sale? War and the transformation of regulation on the Congo-Ugandan border', Development and Change, 41(4), pp. 563-587, DOI: 10.1111/j.1467-7660.2010.01655.x.

Robinson, J. (2006) 'Inventions and Interventions: Transforming Cities - An Introduction', Urban Studies, 43(2), pp. 251-258, DOI: 10.1080/00420980500495812.

Simone, A. (2004) For the City Yet to Come. Changing African Life in Four Cities (Durham and London: Duke University Press).

Trefon, T. (2011) Congo Masquerade: the political culture of aid inefficiency and reform failure, (London, New York and Kampala: Zed Books, Fountain Publishers).

Tull, D. (2003) 'A reconfiguration of political order? The state of the state in North Kivu', African Affairs, 102(308), pp. 429-446, DOI:10.1093/afraf/adgo46.

Turner, T. (2007) The Congo Wars: Conflict, Myth and Reality (London: Zed Books).

United Nations Security Council (2015) Rapport Final du Groupe d'Experts sur la République Démocratique du Congo, S/2015/19, (New York: United Nations).

Verbrugge, D., E. Francq and J. Cuvelier (2011) Guide to current mining reform initiatives in Eastern DRC, IPIS report, https://biblio.ugent.be/publication/1863693/ file/1864032 (accessed on 6 November 2017).

Vlassenroot, K. (2013) South Kivu: identity, territory and power in Eastern Congo (London: Rift Valley Institute).

Vlassenroot, K. and T. Raeymaekers (2004) Conflict and social transformation in Eastern D.R. Congo (Ghent: Academia Press).

Vogel, C. and T. Raeymaekers (2016) 'Terr(it)or(ies) of Peace? The Congolese Mining Frontier and the Fight Against "Conflict Minerals", Antipode 48 (4), pp. 1102-1121.

Vogel, C. and B. Radley (2014) 'In Eastern Congo, economic colonialism in the guise of ethical consumption?', Washington Post, 10 September, https://www.washington post.com/news/monkey-cage/wp/2014/og/10/in-eastern-congo-economic-colonia lism-in-the-guise-of-ethical-consumption/?utm_term $=.49 \mathrm{~b} 40 \mathrm{efi28} \mathrm{c}$ (accessed on 6 November 2017).

Vwakyanakazi, M. (1992) 'Creuseurs d'or et crise socio-économique au Nord Kivu en République du Zaire', Africa, 47(3), pp. 75-391.

Walsh, A. (2003) ' "Hot Money” and daring consumption in a northern Malagasy sapphire-town', American Ethnologist, 3(2), pp. 290-305, DOI: 10.1525/ae.2003.30.2.290. 
Werthmann, K. (2009) 'Working in a boom-town: Female perspectives on gold-mining in Burkina Faso', Resources Policy, 34, pp. 18-23, DOI: 10.1016/j.resourpol.2008.o9.002.

Werthmann, K. (2003) 'Cowries, gold and bitter money: gold mining and notions of ill-gotten wealth in Burkina Faso', Paideuma 49, pp. 105-124.

Werthmann, K. and T. Grätz (2012) Mining Frontiers in Africa. Anthropological and Historical Perspectives (Köln: Rüdiger Köppe Verlag). 